\title{
Penanganan Demam pada Anak
}

\author{
Inke Nadia Diniyanti Lubis, Chairuddin Panusunan Lubis \\ Departemen Ilmu Kesehatan Anak, RS. H. Adam Malik, Fakultas Kedokteran Universitas Sumatera \\ Utara, Medan
}

\begin{abstract}
Fobia demam yang terjadi pada orang tua seringkali mendorong orang tua untuk mencari informasi mengenai penanganan demam pada anak. Definisi demam bervariasi, tetapi banyak yang mendefinisikan demam sebagai temperatur $\geq 38^{\circ} \mathrm{C}$. Pengukuran suhu tubuh anak haruslah mempertimbangkan masalah ekonomis, juga merupakan pengukuran yang sederahana dan cepat dan tidak menimbulkan ketidaknyamanan pada anak. Berbagai penanganan demam telah diketahui secara umum termasuk dengan pemberian antipiretik maupun dengan metode fisik. Jenis antipiretik yang disetujui pemberiannya pada anak ialah parasetamol dan ibuprofen. Pemilihan antipiretik, cara pemberian, dan dosis antipiretik penting untuk diketahui oleh praktisi maupun orangtua dalam menangani demam, sehingga informasi yang lengkap harus diberikan kepada orang tua pada setiap kunjungan untuk mencegah kesalahan pemberian obat dan juga mencegah toksisitas antipiretik. Sari Pediatri 2011;12(6):409-18.
\end{abstract}

Kata kunci: demam, anak, penanganan

$\mathrm{F}$ obia demam" umum terjadi dikalangan orang tua dan pengasuh di Eropa, sehingga seringkali peresepan obat tidak dilakukan sesuai dengan kejadian. ${ }^{1}$ Orang tua sangat khawatir bila anaknya sakit, dan sering mengalami kesulitan dalam menilai keparahan penyakit. Demam dianggap membahayakan dan digunakan sebagai indikator penyakit serius oleh orang tua. Orang tua merasa kesulitan apabila anak mereka sakit, dan merasa tidak memberikan perhatian yang cukup apabila demam tidak dapat diturunkan. Beberapa literatur

\footnotetext{
Alamat korespondensi:

Dr. Inke Nadia Diniyanti Lubis, M.Ked(Ped), Departemen Ilmu Kesehatan Anak, RS. H. Adam Malik, Fakultas Kedokteran Universitas Sumatera Utara, JL. Bunga Lau No. 17 Medan, Sumatera Utara, Indonesia Telp: 061 8365663, Fax: 061 8216264, E-mail: inkenadia@ gmail.com
}

mengenai kekhawatiran orang tua terhadap demam dan mengenai tata laksana demam yang tidak tepat telah dipublikasikan dalam beberapa kurun waktu terakhir. Perkembangan program pendidikan untuk membantu orang tua menangani demam pada anak terbukti efektif. Namun, orang tua tetap khawatir dan salah dalam menangani demam, dan mencari informasi dan kepastian mengenai cara penanganan demam dari keluarga, teman, profesi medis, buku, majalah, dan internet. $^{2}$

Sejak 1980 fobia demam pada orang tua diperkuat dengan konsultasi berlebih kepada praktisi medis mengenai demam ringan, telah menjadi motivasi penelitian di bidang ini. Penelitian yang dilaksanakan pada tahun 1980-an merupakan penelitian deskripsi dan dilakukan di Amerika, Kanada, dan Arab Saudi. Pada dekade ini, hanya dua penelitian intervensi dengan kontrol yang dilaporkan di Amerika Serikat. ${ }^{2}$ 


\section{Metode penelusuran}

Penelusuran dilakukan pada basis data Medline, CINAHL, PsycINFO, PsycARTICLES dan Web of Science dari Januari 1980 sampai Oktober 2004. Artikel disertakan apabila penelusuran berasal dari negara berkembang, ditulis dalam bahasa Inggris, demam yang dipantau pada penyakit anak secara umum (kecuali meningitis dan malaria), dan pada penelitian kuantitatif, besar sampel lebih dari 30. Kata kunci penelusuran adalah demam, anak, orang tua, pendidikan, pengetahuan, kepercayaan, kepedulian, temperatur, antipiretik, informasi, dan kombinasinya. ${ }^{2}$

Identifikasi publikasi dalam bahasa Inggris dan Itali yang berhubungan juga dilakukan melalui penelusuran dari Medline dan the Cochrane Database of Systematic Reviews dari awal penerimaan publikasi hingga 31 Desember 2007. Hasil penelusuran kemudian dievaluasi dan dipilih berdasarkan relevansi dan metodologinya. ${ }^{1}$

\section{Seleksi penelitian, levels of evidence, dan kekuatan rekomendasi}

Seleksi penelitian, evaluasi metodologi penelitian, dan proses ekstraksi data dilaksanakan oleh personil yang terlatih. Pada setiap penelitian evaluasi dan ekstraksi data dilaksanakan dengan menggunakan daftar metodologi yang diadaptasi dan diterjemahkan yang berasal dari Scottish Intercollegiate Guidelines Network. Data yang diekstraksi dari setiap penelitian dirangkum dalam tabel yang spesifik untuk setiap pertanyaan dan tipe penelitian. Tabel rangkuman dibuat dalam format yang direkomendasikan oleh National Institute for health and Clinical Exellence (NICE) atau dalam format yang dibuat khusus oleh panel. Metode NGLP digunakan untuk membagi tingkatan data sesuai 6 tingkatan bukti (I-VI) dan 5 gradasi rekomendasi (A-E). Levels of evidence dibuat berdasarkan metodologi dan bentuk penelitian, sesuai yang dievaluasi oleh panel. Pendapat panel disusun menggunakan metode konsensus Delphi. ${ }^{1}$ (tabel 1)

\section{Pedoman tata laksana demam}

\section{Bagaimana cara pengukuran suhu pada anak yang seharusnya?}

\section{Evidence $^{I}$}

Metode ideal dalam pengukuran suhu tubuh pada anak harus menggambarkan secara akurat temperatur sen-
Tabel 1. Evidence levels dan kekuatan rekomendasi ${ }^{1}$

Evidence levels

I. Lebih dari $>1$ randomized controlled trial dan/atau systematic review of randomized trials

II. Satu randomized controlled trial yang di disain dengan baik

III. Studi kohort non randomisasi dengan kelompok kontrol (baik yang bersamaan ataupun sebelumnya) atau sebuah metaanalisa dari studi-studi tersebut

IV. Studi retrospektif, seperti studi case-control, atau metaanalisa dari studi-studi tersebut

V. Serial kasus tanpa kelompok kontrol

VI. Pendapat ahli atau komite ahli, atau konsensus dari konferensi-konferensi, atau berdasarkan pendapat dari anggota kelompok yang sedang mengembangkan suatu pedoman

Kekuatan rekomendasi

A. Kekuatan rekomendasi sesuai dengan prosedur atau uji diagnostik tertentu; rekomendasi didukung dengan kejadian ilmiah dengan kualitas yang baik, meskipun tidak termasuk dalam tipe I atau II

B. Meragukan apakah prosedur atau intervensi tersebut harus selalu direkomendasikan, tetapi harus selalu masuk ke dalam pertimbangan

C. Tidak meyakinkan apakah prosedur ataupun intervensi sebaiknya atau tidak sebaiknya direkomendasikan

D. Prosedur ataupun intervensi tidak direkomendasikan

E. Prosedur ataupun intervensi sangat tidak direkomendasi kan

tral, ekonomis, sederhana, cepat, dan tidak menyebabkan ketidaknyamanan pada anak. Pengukuran temperatur sentral memerlukan metode invasif, maka temperatur diukur dengan cara yang lebih mudah melalui aksila, oral, rektal, maupun pada membran timpani. Pengukuran temperatur melalui rektal secara umum dianggap yang paling mendekati suhu sentral. Namun, ketika temperatur sentral meningkat atau menurun secara tiba-tiba, temperatur rektal berubah lebih lama dan dapat berbeda dari temperatur sentral. Pemeriksaan rektal tidak direkomendasikan pada pasien keganasan, bayi baru lahir, atau pasien dengan diare, neutropenia atau gangguan imun. Feses atau darah dapat berpengaruh terhadap keakuratan pemeriksaan. 
Sebagai tambahan, metode rektal menyebabkan risiko terjadinya lesi di rektal atau perforasi, serta risiko kontaminasi bakteri oleh karena prosedur pembersihan kurang baik.

Pengukuran di aksila mudah dilakukan, namun memiliki sensitivitas yang bervariasi dan dapat dipengaruhi oleh jenis termometer dan lama pengukuran. Pembacaan di aksila secara umum $0,5^{\circ} \mathrm{C}$ lebih rendah daripada pembacaan rektal, walaupun konversi faktor yang tepat antara dua jenis pengukuran belum ditetapkan. Hasil pengukuran pada aksila akurat pada bayi baru lahir. Pengukuran temperatur tubuh pada oral keakuratannya bervariasi dan dapat dipengaruhi oleh faktor perancu seperti mukositis, makanan panas atau dingin, temperatur udara serta frekuensi pernapasan. Lebih lanjut, pengukuran pada oral memerlukan kerjasama dari pasien. Termometer merkuri seharusnya tidak digunakan untuk pengukuran pada oral karena kemungkinan akan terjadinya keracunan logam.

Termometer digital dapat digunakan untuk pengukuran pada rektal, oral atau aksila, namun hasil mungkin dapat berbeda antara satu sama lain. Tergantung pada perubahan temperatur/waktu pengukuran, dapat berhenti sebelum saatnya, cara pengukuran tersebut tidak digunakan untuk mendapatkan pengukuran yang akurat.

Beberapa peneliti mempertimbangkan pengukuran timpani dengan menggunakan termometer inframerah sebagai metode pengukuran non invasif untuk temperatur sentral. Satu studi melaporkan tingginya keakuratan pada pengukuran dengan metode ini, walaupun beberapa peneliti lain mendapatkan hasil yang bertentangan, terutama ketika pengukuran tidak dilakukan oleh tenaga profesional. Perbedaan model termometer inframerah dapat menyebabkan hasil yang bervariasi. Sebagai tambahan, lekukan liang telinga juga dapat

Tabel 2. Tipe termometer, berdasarkan wawancara telepon dengan sampel acak pada komunitas ahli farmasi di Itali pada tahun $2008^{1}$

\begin{tabular}{|c|c|c|c|c|c|}
\hline $\begin{array}{l}\text { Tipe } \\
\text { Termometer }\end{array}$ & $\begin{array}{l}\text { Tempat/Cara } \\
\text { Pengukuran }\end{array}$ & $\begin{array}{l}\text { Biaya, } \\
\text { Perkiraan, } \\
\quad €\end{array}$ & Keuntungan & Kerugian & Komentar \\
\hline Merkuri & $\begin{array}{l}\text { Aksila, oral, } \\
\text { rektal }\end{array}$ & $2-5$ & $\begin{array}{l}\text { Mudah dibaca, bia- } \\
\text { ya murah }\end{array}$ & $\begin{array}{l}\text { Rapuh, tidak dapat di- } \\
\text { kalibrasi, waktu peng- } \\
\text { ukuran yg lama ( } 5-8 \text { menit } \\
\text { dengan tipe nonprismatik } \\
\text { klasik, berpotensi terhadap } \\
\text { keracunan merkuri }\end{array}$ & $\begin{array}{l}\text { Ditarik dari pasaran } \\
\text { pada tahun } 2010 \text { karena } \\
\text { risiko keracunan mer- } \\
\text { kuri }\end{array}$ \\
\hline Digital & $\begin{array}{l}\text { Aksila, oral, } \\
\text { rektal }\end{array}$ & $4-8$ & $\begin{array}{l}\text { Akurasi tinggi, bi- } \\
\text { aya murah, waktu } \\
\text { pengukuran singkat } \\
\text { (1-2 menit), mem- } \\
\text { punyai alarm akus- } \\
\text { tik yg menandakan } \\
\text { akhir pengukuran }\end{array}$ & $\begin{array}{l}\text { Butuh penggantian ba- } \\
\text { terai, kalibrasi sulit dila- } \\
\text { kukan, beberapa model } \\
\text { bergantung pada per- } \\
\text { ubahan temperatur/ wak- } \\
\text { tu pengukuran dan dapat } \\
\text { berhenti lebih cepat }\end{array}$ & $\begin{array}{l}\text { Model yang fleksibel } \\
\text { lebih dipilih karena } \\
\text { alasan keamanan, ti- } \\
\text { pe "dummy" (pacifier) } \\
\text { mempunyai akurasi yg } \\
\text { kurang }\end{array}$ \\
\hline $\begin{array}{l}\text { Cairan } \\
\text { kristal }\end{array}$ & $\begin{array}{l}\text { Strip plastic di- } \\
\text { tempel pada } \\
\text { dahi }\end{array}$ & $1-2$ & $\begin{array}{l}\text { Mudah digunakan, } \\
\text { tidak rusak, non } \\
\text { toksik }\end{array}$ & $\begin{array}{l}\text { Akurasi dan ketepatan } \\
\text { yang kurang }\end{array}$ & $\begin{array}{l}\text { Tipe "mother's touch" } \\
\text { lebih tepat dibanding } \\
\text { model lainnya }\end{array}$ \\
\hline Inframerah & $\begin{array}{l}\text { Aurikula } \\
\text { Kontak kulit } \\
\text { Non kontak }\end{array}$ & $\begin{array}{l}30-50 \\
25-60 \\
40-90\end{array}$ & $\begin{array}{l}\text { Waktu pengukuran } \\
\text { yg sangat singkat } \\
\text { (beberapa detik) }\end{array}$ & $\begin{array}{l}\text { Tidak ada standarisasi } \\
\text { antar model menyebab- } \\
\text { kan kalibrasi yg tidak } \\
\text { tepat, beberapa model } \\
\text { (aurikula) dapat sulit } \\
\text { untuk dimasukkan, ti- } \\
\text { pe kontak-kulit membu- } \\
\text { tuhkan disinfeksi rutin } \\
\text { atau hanya dikhususkan } \\
\text { pada } 1 \text { pasien }\end{array}$ & $\begin{array}{l}\text { Pengukuran aurikula } \\
\text { dapat memberikan hasil } \\
\text { akurat ketika dilakukan } \\
\text { oleh tenaga ahli }\end{array}$ \\
\hline
\end{tabular}


memberi kesulitan untuk mencapai membran timpani, terutama pada bayi baru lahir. Adanya hiperemia atau kotoran telinga juga dapat mempengaruhi hasil pengukuran. Termometer digital "dummy" (pacifierstyle) dan termometer cairan kristal tidaklah akurat. Hasil pengukuran temperatur tubuh pada kulit dengan menggunakan termometer inframerah harus diinterpretasi dengan hati-hati, dikarenakan berdasarkan laporan jumlah pasien yang terbatas. Begitu juga, masih kurangnya data untuk menyusun rekomendasi mengenai penggunaan termometer alkohol dan gallium.

\section{Rekomendasi ${ }^{1}$}

Rekomendasi 1. Pengukuran rektal seharusnya tidak dilakukan secara rutin pada anak < 5 tahun karena prosedur tersebut invasif dan menimbulkan rasa tidak nyaman (evidence level III, kekuatan rekomendasi D).

Rekomendasi 2. Pengukuran suhu tubuh melalui oral sebaiknya dihindari pada anak (evidence level III, kekuatan rekomendasi D).

Rekomendasi 3. Penggunaan termometer merkuri tidak direkomendasikan karena adanya risiko untuk pecah dan terjadinya toksisitas merkuri (evidence level III, kekuatan rekomendasi E).

Rekomendasi 4. Pengukuran aksila menggunakan termometer digital direkomendasikan pada anak $<4$ minggu (evidence level III, kekuatan rekomendasi B).

Rekomendasi 5. Di rumah sakit atau rawat jalan, pengukuran aksila dengan menggunakan termometer digital atau pengukuran timpani dengan menggunakan termometer inframerah direkomendasikan untuk anak usia $\geq 4$ minggu (evidence level II, kekuatan rekomendasi B).

Rekomendasi 6. Untuk pengukuran di rumah oleh orangtua atau pengasuh, pengukuran aksila dengan menggunakan termometer digital direkomendasikan pada semua anak (evidence level II, kekuatan rekomendasi B). Penggunaan termometer inframerah pada timpani tidak direkomendasikan, sebab cenderung mengalami kesalahan tergantung dari operator.

\section{Apakah penggunaan metode fisik sesuai untuk menurunkan temperatur tubuh anak?}

\section{Evidence $^{I}$}

Metode fisik untuk menurunkan demam termasuk memandikan, mengelap badan, pemaparan dengan air dingin, penggunaan selimut dingin atau kantung es, dan menggosokkan tubuh dengan alkohol. Penggunaan metode fisik dapat berhubungan dengan efek samping, termasuk peningkatan demam yang paradoksikal sebagai akibat dari terjadinya vasokonstriksi yang dipicu oleh penurunan temperatur tubuh, gemetar dan menggigil yang lama, meningkatnya penurunan energi akibat demam itu sendiri, dan hipoglikemia berat, koma ataupun kematian yang berhubungan dengan penggunaan busa mandi dengan etil atau isopropil alkohol. Mengelap tubuh dengan air suamsuam kuku belum pernah dikaitkan dengan terjadinya efek samping yang berat, meskipun berkaitan dengan rasa tidak nyaman.

Penggunaan metode fisik ini tidak menguntungkan pada anak dengan demam, karena dampaknya terbatas dan sementara, dan tidak berpengaruh terhadap mekanisme pusat pengendali temperatur tubuh. Penggunaan metode fisik ini direkomendasikan pada kasus hipertermia, karena suhu tubuh meningkat sendiri tanpa pengaruh kerja pusat pengendali suhu (seperti, heat stroke dan sunstroke).

\section{Rekomendasi ${ }^{1}$}

Rekomendasi 7. Penggunaan metode fisik untuk menurunkan demam tidak direkomendasikan (evidence level I; kekuatan rekomendasi E).

Rekomendasi 8. Penggunaan metode fisik direkomendasikan pada kasus hipertermia (evidence level I; kekuatan rekomendasi A).

\section{Apakah terdapat hubungan antara derajat demam dengan derajat penyakit dasar?}

\section{Evidence $^{I}$}

Beberapa studi pada anak menemukan adanya hubungan antara suhu tubuh $\geq 41,1^{\circ} \mathrm{C}$ dengan risiko bakterimia dan infeksi bakteri invasif, sementara beberapa studi 
tidak menemukan adanya hubungan. Secara tersendiri, suhu tubuh yang tinggi $\left(>39^{\circ} \mathrm{C}\right)$ memiliki sensitivitas dan spesifisitas yang rendah untuk infeksi bakteri berat. Demam tinggi menjadi faktor risiko hanya bila dihubungkan dengan variabel lainnya, seperti jumlah leukosit atau nilai CRP yang tinggi. Sebagai tambahan, respon terhadap obat antipiretik bukan merupakan faktor prediksi terhadap penyebab demam.

\section{Rekomendasi ${ }^{1}$}

Rekomendasi 9. Derajat demam tidak dapat dijadikan sebagai indikator terhadap risiko adanya infeksi bakteri berat (evidence level III; kekuatan rekomendasi E).

Rekomendasi 10. Pada beberapa keadaan, misalnya usia $<3$ bulan adanya leukositosis atau peningkatan CRP dan demam tinggi yang terjadi bersamaan, dapat menjadi faktor prediktif terhadap infeksi bakteri berat (evidence level III, kekuatan rekomendasi C).

\section{Apakah pemberian antipiretik dianjurkan pada anak dengan demam ?}

\section{Evidence $^{I}$}

Demam merupakan salah satu bagian dari pertahanan fisiologi alamiah dalam melawan agen infeksi. Mekanisme imunologis meningkat dengan adanya demam dan kemampuan virus dan bakteri untuk bereplikasi akan menurun. Suatu randomized controlled trial pada anak dengan varisela menemukan bahwa pemberian parasetamol (asetaminofen) tidak mengurangi gejala demam dan dapat memperpanjang proses penyakit. Walaupun demikian, praktisi klinis sering mengobati demam, dengan pemberian obat antipiretik untuk mengurangi ketidaknyamanan anak.

Obat antipiretik yang disetujui untuk digunakan pada anak adalah parasetamol dan ibuprofen. Penggunaan asetilsalisilat sangat tidak dianjurkan pada anak usia $<15$ tahun oleh karena risiko terhadap sindrom Reye. Steroid tidak bisa digunakan pada anak dengan demam karena rasio keuntungan-kerugian yang rendah. Dari kelompok NSAIDs, ibuprofen memiliki risiko yang terkecil terhadap efek samping gastrointestinal. Metaanalisis dari 12 studi memberikan hasil yang tidak meyakinkan bahwa parasetamol memiliki efikasi antipiretik yang lebih baik dibandingkan dengan plasebo, walaupun hasil ini dipengaruhi oleh jumlah pasien yang sedikit dalam studi.

Menurut pedoman NICE, antipiretik tidak bisa digunakan secara rutin pada penanganan anak dengan demam, walaupun dapat digunakan pada anak yang menunjukkan gejala ketidaknyamanan, termasuk menangis berkepanjangan, iritabilitas, aktivitas yang berkurang, selera makan menurun, dan gangguan tidur. Sebaliknya pedoman WHO menganjurkan penggunaan parasetamol apabila suhu tubuh $>39^{\circ} \mathrm{C}$. Dan dokumen terbaru dari WHO tidak menganjurkan penggunaan rutin antipiretik pada anak, terutama pada situasi keluarga harus menanggung biaya pengobatan dan juga karena peran obat antipiretik pada anak dengan malaria, sepsis atau malnutrisi kronik masih belum ditetapkan.

\section{Rekomendasi ${ }^{1}$}

Rekomendasi 11. Penggunaan antipiretik pada anak direkomendasikan hanya bila demam berhubungan dengan adanya kejadian ketidaknyamanan (misalnya menangis yang berkepanjangan, iritabilitas, pengurangan aktivitas, selera makan yang menurun, gangguan tidur) (evidence level I; kekuatan rekomendasi B).

\section{Bagaimana pemilihan antipiretik dan cara pembe- riannya}

\section{Evidence $^{1}$}

Pada satu metaanalisis dari 8 penelitian membandingkan efikasi antara antipiretik parasetamol dan ibuprofen didapati penurunan temperatur tubuh yang lebih tinggi pada anak yang diobati dengan ibuprofen dibandingkan dengan parasetamol pada pengukuran setelah 4 jam (perbedaan $0,63^{\circ} \mathrm{C}, \mathrm{p}<$ 0,001 ) dan pada 6 jam setelah pemberian (perbedaan $\left.0,58^{\circ} \mathrm{C}, \mathrm{p}=0,005\right)$. Bagaimanapun, penulis tidak memasukkan rincian dari strategi penelitian mereka, dan memasukkan penelitian dengan penggunaan dosis obat yang berbeda dan mengeksklusikan penelitian yang mengukur temperatur tubuhnya di luar jam ke-4 dan ke-6.

Suatu metaanalisis pada 17 penelitian yang membandingkan efek antipiretik ibuprofen dan 
parasetamol, hasil akhir dinilai berdasarkan besar penurunan demam setelah dosis tunggal awal dari kedua antipiretik. Pada jam ke- 4 dan ke-6 setelah pemberian antipiretik, penurunan demam terjadi $15 \%$ lebih banyak pada anak di kelompok ibuprofen, dibandingkan dengan kelompok paracetamol (besar efek penurunan setelah 2 jam: 0,19 (CI95\%, 0,05-0,33), besar efek penurunan setelah 4 jam: 0,31 (CI95\%, 0,19-0,44), besar efek penurunan setelah 6 jam: 0,33 (CI95\%, 0,19-0,47). Sebuah tinjauan narasi dari 22 penelitian mendapatkan bahwa dosis tunggal ibuprofen lebih efektif dalam menurunkan demam dibandingkan dengan dosis tunggal parasetamol, dimana ibuprofen lebih efektif setelah 6 jam pemberian, tetapi tidak setelahnya (temperatur dievaluasi sampai 8 jam), dan tidak ada perbedaan yang signifikan antara efek antipiretik satu obat atau yang lain pada penelitian yang melibatkan dosis yang multipel.

Risiko dari efek samping telah dilaporkan sama antara ibuprofen dan parasetamol. Pada uji terbaru, efek antipiretik dari ibuprofen tampak lebih cepat dan bertahan lama dibandingkan dengan parasetamol. Bagaimanapun, perbandingan langsung antara ibuprofen dan parasetamol bukan merupakan tujuan utama dari studi tersebut, dan perbedaaan tersebut tidak tampak secara relevan berhubungan terhadap klinis.

\section{Rekomendasi ${ }^{1}$}

Rekomendasi 12. Parasetamol dan ibuprofen merupakan antipiretik yang direkomendasikan untuk digunakan pada anak-anak (evidence level I ; kekuatan rekomendasi A).

Rekomendasi 13. Penggunaan asam asetil salisilat pada anak tidak direkomendasikan karena risiko terjadi sindrom Reye (evidence level III; kekuatan rekomendasi E).

Rekomendasi 14. Rasio keuntungan-kerugian yang lemah, steroid sebaiknya tidak digunakan sebagai antipiretik pada anak (evidence level III; kekuatan rekomendasi E).

Rekomendasi 15: Kombinasi atau penggunaan yang bergantian antara parasetamol dan ibuprofen tidak direkomendasikan (evidence level VI; kekuatan rekomendasi D).

\section{Bagaimanakah pemberian parasetamol yang lebih baik, per rektal atau per oral?}

\section{Evidence $^{I}$}

Sediaan oral dan rektal dari parasetamol sering digunakan secara bergantian dengan asumsi keduanya memiliki efek antipiretik yang sama.

\section{Rekomendasi ${ }^{1}$}

Rekomendasi 16. Pemberian oral parasetamol lebih baik digunakan daripada pemberian rektal pada anak, karena absorpsi lebih konstan dan lebih memungkinkan untuk memberikan dosis sesuai dengan berat badan (evidence level I; kekuatan rekomendasi A).

Rekomendasi 17. Pemberian parasetamol rektal hanya dipertimbangkan bila anak muntah atau pemberian oral tidak memungkinkan (evidence level I; kekuatan rekomendasi A).

Rekomendasi 18. Dosis rektal parasetamol yang melebihi dosis standar harus dihindari pada anak karena meningkatkan risiko toksisitas (evidence level I; kekuatan rekomendasi A).

Rekomendasi 19. Penggunaan parasetamol rektal harus berdasarkan berat badan daripada umur. Jika dosis yang tersedia dalam kemasan supositoria melebihi dosis yang sesuai berdasarkan berat badan, harus dipilih rute pemberian yang lain (evidence level I, kekuatan rekomendasi $\mathrm{A}$ ).

\section{Apakah antipiretik ditoleransi dengan baik pada anak?}

\section{Evidence $^{1}$}

Baik ibuprofen dan parasetamol ditoleransi dengan baik pada anak. Dua studi acak melaporkan risiko hospitalisasi yang rendah akibat perdarahan gastrointestinal, gagal ginjal, atau anafilaksis pada penggunaan parasetamol maupun ibuprofen. Pada 27.065 anak demam usia 6 bulan hingga 2 tahun yang dirandomisasi mendapatkan parasetamol atau ibuprofen, risiko perawatan karena penyebab 
apapun 1,4\% (CI95\%, 1,3-1,6\%) dan tidak berbeda berdasarkan antipiretik yg didapat. Tidak ada anak yang dirawat akibat gagal ginjal akut atau anafilaksis.

Penggunaan ibuprofen pada pasien dengan dehidrasi sebaiknya berhati-hati dikarenakan meningkatnya risiko gagal ginjal. Penggunaan ibuprofen tidak direkomendasikan pada anak dengan varisela karena berpotensi meningkatkan risiko superinfeksi pada kulit dan jaringan lunak dan infeksi Streptokokus invasif. Beberapa laporan kasus menunjukkan peningkatan risiko empiema torasik yg berhubungan dengan penggunaan ibuprofen. Penggunaan ibuprofen harus dihindari pada pasien Kawasaki yang telah mendapat asam asetilsalisilat, karena menghambat efek akhir dari anti agregasi trombosit.

\section{Rekomendasi $^{1}$}

Rekomendasi 20. Parasetamol dan ibuprofen ditoleransi dengan baik dan merupakan antipiretik yang efektif ketika digunakan sesuai dosis yang direkomendasikan. Untuk parasetamol oral, dosis standar $10-15 \mathrm{mg} / \mathrm{kg}$ per dosis (maksimum, $1 \mathrm{gr}$ per dosis) diberikan 4-6 kali per hari. Dosis terapeutik maksimum $60 \mathrm{mg} / \mathrm{kg}$ per hari pada anak usia $<3$ bulan dan $80 \mathrm{mg} / \mathrm{kg}$ per hari pada anak usia $\geq 3$ bulan (maksimum, $3 \mathrm{gr} / \mathrm{hari}$ ), dan dosis toksik ialah $>150 \mathrm{mg} / \mathrm{kg}$ pada pemberian tunggal. Untuk ibuprofen oral, dosis standar $10 \mathrm{mg} / \mathrm{kg}$ per dosis (maksimum, 800 mg per dosis) diberikan 3 atau 4 kali sehari. Dosis terapeutik maksimum $30 \mathrm{mg} / \mathrm{kg}$ per hari (maksimum, 1,2 gr/hari), dan dosis toksik $>100 \mathrm{mg} / \mathrm{kg}$ per hari (level level I; kekuatan rekomendasi A).

Rekomendasi 21. Penggunaan ibuprofen tidak direkomendasi pada anak dengan varisela atau dehidrasi (evidence level $V$; kekuatan rekomendasi D).

\section{Hal apa yang harus diperhatikan untuk mencegah toksisitas antipiretik pada anak?}

\section{Evidence $^{1}$}

Toksisitas parasetamol dapat terjadi setelah pemberian dosis tunggal yang tinggi atau dosis multipel yang berlebihan, dan dapat berhubungan dengan efek samping yang sangat fatal yaitu nekrosis hepar akut. Meskipun dosis tunggal parasetamol $150 \mathrm{mg} / \mathrm{kg}$ dilaporkan sebagai batas untuk toksisitas hati pada anak, toksisitas yang berat telah dilaporkan pada pemberian dosis yang lebih rendah.
Anak dengan diabetes, riwayat keluarga dengan reaksi toksisitas hati, obese, malnutrisi kronik, dan menjalani puasa yang panjang mempunyai risiko yang lebih tinggi terhadap toksisitas hati. Sangat disayangkan evidence atas toksisitas hepar dengan dosis terapeutik parasetamol sangatlah sedikit.

Penggunaan antipiretik tanpa pemberian resep dan/ atau tanpa pengawasan medis meningkatkan risiko overdosis. Dilaporkan sebagian dari orangtua membawa anaknya yang berusia $\leq 10$ tahun ke instalasi gawat darurat dalam 24 jam setelah memberikan parasetamol ataupun ibuprofen dengan dosis yang diketahui orangtua sebagai dosis antipiretik, tetapi ternyata sebagai dosis terlalu tinggi. Anak usia $<1$ tahun mempunyai risiko yang lebih besar untuk mendapatkan dosis yang tidak tepat. Pada satu studi mengenai kesalahan pemberian dosis pada pengobatan dengan sirup, kesalahan tersering ialah akibat misinterpretasi informasi pada leaflet dan penggunan sendok teh atau sendok makan dibanding dengan penggunaan sendok takar atau spuit oral.

Risiko overdosis yang lebih besar telah dilaporkan pada pemberian rektal dibanding pemberian oral parasetamol, terutama pada anak yang lebih kecil. Penyebab tersering overdosis ialah pemberian produk over-the-counter yang mengandung parasetamol sebagai tambahan parasetamol yang telah diresepkan oleh dokter. Saran dan cara penentuan dosis antipiretik sebaiknya dijelaskan kepada orangtua pada setiap kunjungan seperti pada Tabel 3.

Menjelaskan tanda dan gejala dari toksisitas antipiretik (anoreksia, nausea, muntah, oliguria, nyeri perut, hiporesponsif, hipotermia) dan meyakinkan pentingnya untuk segera membawa anak ke instalasi gawat darurat ketika gejala tersebut timbul

Anak tersangka keracunan parasetamol harus dirujuk segera ke instalasi gawat darurat. Meskipun beberapa tanda yang tidak spesifik (seperti anoreksia, nausea, muntah, ketidaknyamanan, dan diaforesis) yang dapat muncul pada fase awal dari keracunan parasetamol, seringkali tidak terlihat. Bahkan overdosis yang serius dapat asimptomatik. Pemberian $\mathrm{N}$-acetylcysteine untuk keracunan parasetamol akut paling efektif jika diberikan dini.

Beberapa kasus dari 20 kasus keracunan ibuprofen akut pada anak yang telah dilaporkan merupakan kasus fatal. Dosis ibuprofen $<100 \mathrm{mg} / \mathrm{kg}$ jarang memberik efek toksik pada anak, dosis $>400 \mathrm{mg} /$ $\mathrm{kg}$ berhubungan dengan toksisitas berat. Gambaran klinis dari keracunan ibuprofen ialah nausea, muntah, 
Tabel 3. Saran dan informasi

- Menyediakan informasi yang jelas mengenai formulasi obat, dosis yang tepat, dosis maksimum harian, interval pemberian dosis, dan lama terapi.

- Penjelasan bagaimana menghitung dosis berdasarkan berat badan anak dalam kilogram.

- Mendemonstrasikan cara penggunaan yang benar dari alat pengukur dosis, meminta orangtua untuk mengulangi instruksi dan memberitahu bahwa memberikan tanda pada alat pengukur dapat membantu untuk menandakan dosis yang benar.

- Tidak menyarankan formulasi dewasa pada anak (contoh, membagi dosis dewasa).

- Tidak menyarankan penggunaan formulasi rektal tanpa saran medis karena kesulitan pencapaian dosis per kilogram yang tepat .

- Penjelasan mengenai perbedaan konsentrasi pada parasetamol sirup dan drops.

- Menghilangkan pengertian bahwa semakin banyak obat dikonsumsi anak, maka demam akan semakin cepat terkontrol.

- Penjelasan bahwa obat harus diberikan oleh orang dewasa.

- Menyediakan informasi mengenai risiko dari overdosis antipiretik.

nyeri kepala, nyeri epigastrial, gangguan penglihatan, dan takikardia, kejadian yang lebih jarang termasuk kolaps kardiosirkulasi, asidosis, hipokalsemia, hipomagnesemia, hipotermia, perdarahan paru dan gastrointestinal, gagal ginjal, dan gagal organ multipel. Vertigo, krisis apnea, kejang dan penurunan kesadaran (termasuk koma) telah dilaporkan. Bersamaannya dengan penyakit hati kronis meningkatkan risiko toksisitas ibuprofen. Pada kasus terminumnya ibuprofen dengan dosis $>100 \mathrm{mg} / \mathrm{kg}$ atau pada anak yang muncul dengan gejala, activated charcoal harus diberikan.

\section{Rekomendasi ${ }^{1}$}

Rekomendasi 22. Dosis harus diberikan menggunakan alat pengukur yang disediakan beserta dengan paket obat (evidence level $V$; kekuatan rekomendasi A).

Rekomendasi 23. Sangat penting bagi klinisi untuk menilai faktor yang dapat meningkatkan risiko keracunan ibuprofen (misal, varicella, dehi- drasi, terapi bersamaan dengan penghambat ACE, cyclosporine, metotreksat, litium, baklofen, diuretik, kuinolon, dan derivat dikumarol) atau oleh parasetamol (diabetes, obesitas, malnutrisi, risiko keluarga dengan reaksi hepatotoksik, puasa lama, terapi bersamaan dengan karbamazepin, isoniazid, fenobarbital dan barbiturat lainnya, pirimidon, dan rifampisin) (evidence level $V$; kekuatan rekomendasi A).

Rekomendasi 24. Ketika keracunan antipiretik dicurigai, anak harus segera dirujuk ke pusat perawatan keracunan atau instalasi gawat darurat, sebagai intervensi yang cepat berkaitan dengan prognosis yang lebih baik (evidence level I; kekuatan rekomendasi A).

\section{Dapatkan antipiretik digunakan anak dengan kondisi penyakit kronis?}

\section{Evidence $^{I}$}

Beberapa randomized controlled trial telah melaporkan tolerabilitas dari parasetamol dan ibuprofen pada kelompok usia anak seringkali tidak memasukkan anak dengan kondisi penyakit kronis. Pada investigasi sebuah metaanalisis dengan 3 buah RCT pada anak demam, didapati tidak adanya hubungan yang signifikan antara penggunaan parasetamol atau ibuprofen dengan episode asma. Penggunaan parasetamol telah diduga berhubungan dengan peningkatan yang sedang terhadap risiko wheezing.

Pada anak dengan kardiopati kronis, penggunaan parasetamol dan ibuprofen harus dengan peringatan untuk mencegah terjadinya kelebihan beban kardiovaskular yang dapat terjadi selama demam. Kemungkinan terjadinya interaksi ibuprofen dengan obat antihipertensi dan diuretik harus dipertimbangkan, dibutuhkan studi spesifik lebih lanjut.

\section{Rekomendasi ${ }^{1}$}

Rekomendasi 25. Penggunaan ibuprofen dan parasetamol tidak kontraindikasi pada anak penderita asma dengan demam. Parasetamol dan 
ibuprofen kontraindikasi pada kasus paracetamol- atau NSAID induced asthma (evidence level I; kekuatan rekomendasi A).

Rekomendasi 26. Kurangnya data untuk evaluasi penggunaan parasetamol dan ibuprofen pada anak demam dengan kelainan kronik lainnya (contoh, malnutrisi, kardiopati kronik, dan hepatopati kronik). Peringatan dibutuhkan pada kasus gagal hati berat atau gagal ginjal berat atau pada anak dengan malnutrisi berat (evidence level III; kekuatan rekomendasi $\mathrm{C}$ ).

Bagaimanakah tata laksana demam pada anak usia $<28$ hari?

\section{Evidence $^{1}$}

Perawatan selalu direkomendasikan pada neonatus dengan demam karena tingginya risiko terjadinya komplikasi berat. Meskipun ibuprofen dapat diberikan pada neonatus dengan indikasi lain (contoh, pada pengobatan untuk penyakit kardiologi), parasetamol merupakan satu-satunya yang direkomendasikan oleh NICE sebagai antipiretik pada neonatus.

\section{Rekomendasi ${ }^{1}$}

Rekomendasi 27. Neonatus dengan demam usia < 28 hari harus dirawat karena risiko penyakit berat yang meningkat (evidence level I; kekuatan rekomendasi A).

Rekomendasi 28. Parasetamol merupakan satusatunya antipiretik yang diberikan pada neonatus. Dosis dan frekuensi pemberian pada neonatus harus disesuaikan berdasarkan usia gestasi (evidence level III; kekuatan rekomendasi A).

Apakah sebaiknya antipiretik digunakan dalam mencegah kejadian ikutan pasca immunisasi?

\section{Evidence}

Satu systematic review mengenai 5 studi mengemukakan bahwa tidak adanya keuntungan yang berhubungan dengan penggunaan ibuprofen atau parasetamol dalam mencegah efek samping (termasuk demam) akibat vaksinasi. Satu studi pada > 300 anak yang divaksinasi terhadap difteri, tetanus, dan pertussis (DTP) mendapatkan tidak adanya efek protektif dari parasetamol atau ibuprofen pada insidens demam, eritema, nyeri, edema, ataupun gatal. Pada 3 studi acak mengenai vaksin DTP, baik parasetamol dan ibuprofen yang diberikan sebelum atau pada saat vaksinasi dan setiap 4-8 jam hingga setidaknya 12 jam setelahnya menunjukkan efektivitas yang signifikan dalam menurunkan demam, nyeri dan reaksi lokal dibanding plasebo $(\mathrm{p}<0,01)$. Sehingga, penggunaan antipiretik dapat diindikasikan dalam menurunkan insidens efek samping pada vaksinasi DTP. ${ }^{1}$

\section{Rekomendasi}

Rekomendasi 29. Penggunaan parasetamol atau ibuprofen tidak direkomendasikan untuk menurunkan kejadian demam dan reaksi lokal pada anak yang mendapatkan vaksinasi (evidence level II; kekuatan rekomendasi E). ${ }^{1}$

\section{Apakah sebaiknya antipiretik diberikan untuk mencegah kejang demam pada anak?}

\section{Evidence}

Dua tinjauan uji klinis mengenai penggunaan antipiretik untuk mencegah kejang demam menyimpulkan meskipun adanya keterbatasan metodologi pada studi yang tersedia, tidak didapatinya hasil yang positif atas penggunaan tersebut. ${ }^{1}$

\section{Rekomendasi}

Rekomendasi 30. Penggunaan parasetamol atau ibuprofen sebagai pencegahan tidak direkomendasikan dalam mencegah kejang demam pada anak demam (evidence level I; kekuatan rekomendasi E). ${ }^{1}$

\section{Kesimpulan}

Pengukuran temperatur tubuh di aksila menggunakan termometer digital direkomendasikan pada anak usia $<4$ minggu. Sedangkan untuk anak usia $\geq 4$ minggu, 
direkomendasikan pengukuran di aksila dengan termometer digital atau pengukuran di timpani menggunakan termometer inframerah. Untuk pengukuran temperatur tubuh oleh orangtua di rumah, dianjurkan penggunakan termometer digital. Anak yang pada pemeriksaan fisik tidak dijumpai demam tetapi dilaporkan oleh orangtua mengalami demam, harus dipertimbangkan sedang menderita demam.

Pada bayi kecil, demam tinggi dapat sebagai faktor prediktif untuk terjadinya infeksi bakteri berat. Penggunaan metode fisik untuk menurunkan demam tidak dianjurkan, kecuali dalam kasus hipertermia. Penggunaan antipiretik parasetamol (acetaminophen) atau ibuprofen direkomendasikan untuk menurunkan demam untuk mengurangi ketidaknyamanan. Penggunaan kombinasi atau alternatif antipiretik tidak dianjurkan. Dosis antipiretik harus berdasarkan berat badan anak bukan berdasarkan usia. Pemberian oral parasetamol lebih dianjurkan dibanding pemberian rektal, apabila memungkinkan penggunaan ibuprofen tidak direkomendasikan pada anak demam disertai varicella atau dehidrasi. Penggunaan ibuprofen atau parasetamol tidak dikontraindikasikan pada anak demam dengan asma. Data masih sangat terbatas untuk membentuk rekomendasi dalam hal penanganan demam pada anak dengan kondisi kronis, tetapi peringatan harus diberikan pada kasus gagal hati berat atau gagal ginjal berat atau malnutrisi berat. Bayi baru lahir dengan demam harus dirawat inap karena risiko yang meingkat terhadap penyakit berat, parasetamol dapat diberikan tetapi dengan penyesuaian dosis berdasarkan usia gestasi. Penggunaan parasetamol atau ibuprofen tidak efektif dalam mencegah kejang demam atau efek samping dari vaksinasi. ${ }^{1}$

\section{Daftar pustaka}

1. Chiappini E, Principi N, Longhi R. Management of fever in children: summary of the Italian Pediatric Society guidelines. Clin Ther 2009; 31: 1826-43.

2. Walsh A, Edwards H. Management of childhood fever by parents: literature review. J Adv Nurs 2006; 54: 217 27.

3. Tolan RW Jr. Fever of unknown origin: a diagnostic approach to this vexing problem. Clin Pediatr 2010; 49: 207-13.

4. Baraff LJ. Management of infants and young children with fever without source. Pediatr Ann 2008; 37: 673-9.

5. Lierl M. Periodic fever syndromes: a diagnostic challenge for the allergist. Allergy 2007; 62: 1349-58.

6. Klinkhammer MD, Colletti JE. Pediatric myth: fever and petechiae. CJEM 2008; 10: 479-82. 